\title{
Ensuring adequate financing of family planning commodities and services
}

Moazzam Ali

Benjamin Bellows

Population Council

Follow this and additional works at: https://knowledgecommons.popcouncil.org/departments_sbsr-rh

Part of the Demography, Population, and Ecology Commons, Family, Life Course, and Society Commons, Health Policy Commons, International Public Health Commons, Maternal and Child Health Commons, and the Women's Health Commons How does access to this work benefit you? Let us know!

\section{Recommended Citation}

Ali, Moazzam and Benjamin Bellows. 2018. "Ensuring adequate financing of family planning commodities and services," Family Planning Evidence Brief. Geneva: World Health Organization. 


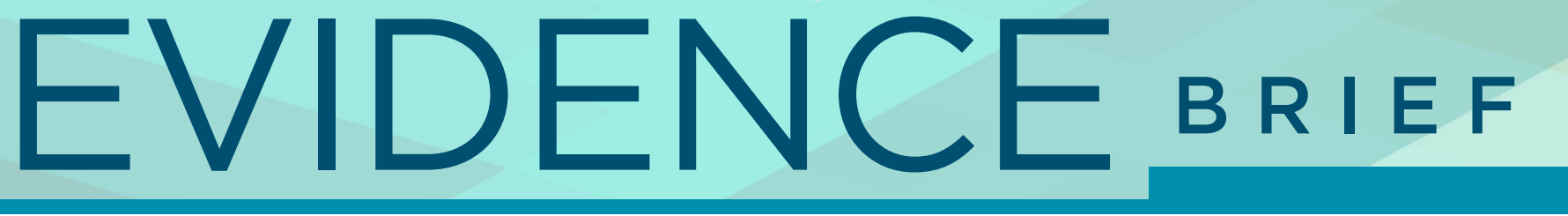

\section{Family Planning Financing}

\section{$\rightarrow$ Ensuring Adequate Financing of Family Planning Commodities and Services}

Increasing efficient and effective investment in family planning through the public and private sectors is key to meeting the FP2O2O goal of helping 120 million additional women become modern contraceptive users. Despite efforts by country governments, donors and individuals are responsible for nearly half (49\%) of the costs of reproductive, maternal, neonatal, and children's health (1). Household expenditures dwarf the contributions of both domestic and international funding sources. Future efforts to reduce unmet need for FP must consider consumers' out-of-pocket costs, programmatic cost-effectiveness, and sources of funding.

\section{CHALLENGES TO FINANCING FAMILY PLANNING}

The estimated direct and indirect annual cost of providing modern contraceptive services to 671 million users in developing regions is US\$6.3 billion (2). Direct costs include contraceptives, supplies, and health worker salaries. Indirect costs include programme support, information and education on FP, construction and maintenance of facilities, and supply chain management. This results in a total average (including direct and indirect) cost for modern contraception per person per year in developing regions of US\$1.01.

Expanding and improving services to meet the needs of all women and girls in developing regions (an additional 214 million) for modern contraception would cost US $\$ 12$ billion annually (including direct and indirect) or US\$1.93 per person per year (2).

The average cost per person in developing regions for modern contraceptive services and maternal and newborn care is US $\$ 8.56$ or US $\$ 53.6$ billion annually (2). Investing in both contraceptive and maternal and newborn services together results in a net savings of $\$ 6.9$ billion compared with investing in maternal and newborn health care alone.

If current trends in increased contraceptive use in 148 developing countries and territories continue, there will be a funding gap of US $\$ 322$ million in 2020 for commodities alone (2). If the FP2O2O goal were fully achieved, the remaining funding gap between amounts spent on supplies in 2014 and 2020 would be US $\$ 541$ million (3).

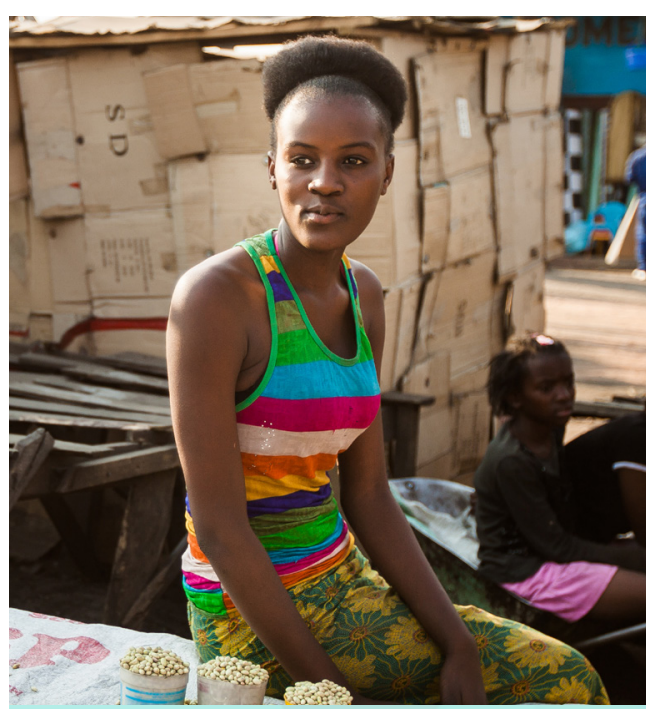

\section{POLICY AND PROGRAMME CONSIDERATIONS}

$\rightarrow$ Ensure sustained fundraising, pooling, and strategic purchasing in order to scale up delivery systems for contraceptive methods.

$\rightarrow$ Increase the number of additional family planning users by reaching new users and improving continuation rates among current users.

$\rightarrow$ Conduct further research on family planning quality performance metrics, such as the method information index, to test their correlation with higher continuation rates. Client dissatisfaction and discontinuation represent significant risks to the success of FP2O2O. 


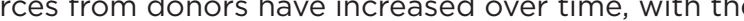
US historically being the largest bilateral donor followed by the bilateral funding for FP. contributing US $\$ 638$ million, and the UK contributed US\$269.9 million (20\%) (4).

There are also multilateral sources of funding, with the UNFPA spending about $43 \%$ of its funds or US $\$ 341$ million on FP in 2015 and the World Bank spending US $\$ 251$ millio on population and reproductive health. (4). Following the Bank is expected to have a greater role in FP (4).

Foundations and the private sector have also made sizeable contributions to reproductive health, with the Bill \& Melinda Gates Foundation, for example, spending US\$148 million for family planning in 2015 (4). And pharmaceutical companies have played a role in partnership with donors through

innovative financing mechanisms that have seen significant eductions in the price of contraceptives - most notably by Bayer and Merck for contraceptive implants.

However, the outlook for future donor funding is uncertain given the instability in currency exchange rates, changing donor-country political agendas, creation of the GFF, and other global developments. The 2018 US budget withheld contribution to UNFPA and level funded family planning, however significant reductions are planned in 2017 (4).

Moreover, domestic funding commitments are highly variable between countries. Domestic financing will likely require more engagement of ministries of finance as well as ministries of health to emphasize the demographic dividend. The demographic dividend is an increase in economic growth and development that could be achieved if changes in the population age structure result in declining fertility rates as a result of increased contraceptive use coupled with investments to improve education, job creation, efficiency in revenue generation and tax collection, and increased tax rates (i). Greater integration of public and private sectors in service delivery, pooling of procurement, and strategic purchasing will lead to more efficient and higher per capita spending with more poputeris in populations in low income countries requires an integrated

\section{CONSIDERATIONS FOR ENSURING ADEQUATE FINANCING OF FAMILY PLANNING COMMODITIES \\ AND SERVICES}

easing the number of additional $F$ users is 列 rates among current users $(5,6)$. Further research on FP quality performance metrics, such as the method information index, is needed to test their correlation with improved continuation rates. Particularly as contraceptive prevalence increases, client dissatisfaction and discontinuation represent a significan risk to the success of the FP2O2O initiative (7).

Achieving universal access to family planning would have one of the highest benefit-cost ratios among wide choice of policy options for development (8). Social and economic benefits for women, their families, and societies will result from increases in women's and children's education, increases in women's earnings, and is muer reductions in poverty (2). In health, prevention is much cheaper than treatment, the cost of moder contraception is much lower than providing care for in FP above the current Fovel the cost of predlar spent r a a (2). If needs for modern contraction and materna (2) net savings of US 609 billion com, the result would be a net savings of US\$6.9 billon compared with investing in in modern contraception will provide a great return on investment that compounds over time (12).

\section{REFERENCES}

Lie, G.S., A.L. Soucat, and S. Basu. 2015. "Financing women's, Children's, and adolescents health," British Medical Journal Sep. 14, 351: h4267.

2 Guttmacher Institute. 2017. Adding It Up: Investing in Contraception and Maternal and Newborn Health, 2017. New York: Guttmacher Institute, December 6 .

3 Reproductive Health Supplies Coalition. 2016. "Global Contraceptive Commodity Gap Analysis 2016." Brussels: Reproductive Health Supplies Coalition. https://www. Thsupplies.org/uploads/2__r Copublications/Global_ accessed on June 14, 2017 .

4 The U.S. Government and International Family Planning \& Reproductive Health Efforts https://www.kff.org/ global-health-policy/fact-sheet/the-u-s-governmentand-international-family-planning-reproductive-healthefforts/

5 Kaiser Family Foundation. 2017. "Family Planning \& Reproductive Health Funding." Menlo Park, CA: Kaiser Family Foundation. http://www.kff.org/interactive/ budget-tracker/summary/Filter-Program-Area/FamilyPlanning_Reproductive-Health/Agency/?view=compareyears\&start Year=2017\&endYear=2018 (Accessed on June 14, 2017)

6 Dasgupta, A., M. Weinberger, B. Bellows, and W. Brown. 2017. " New users'are confusing our counting: Reaching consensus on how to measure 'additional users' of family planning," Global Health: Science and Practice 5(1): 6-14. Retrieved from http://www.ghspjournal.org/ content $/ 5 / 1 / 6$.full.html

7 Jain, A.K., F. Obare, S. RamaRao, and I. Askew. 2013. "Reducing unmet need by supporting women with and Reproductive Health 39(3): 133-141 https://do org/10.1363/3913313

8 Castle, S. and I. Askew. 2015. Contraceptive Discontinuation: Reasons, Challenges and Solutions. New York: Population Council. Retrieved from http:// www.familyplan

9 Kohler, H. and J.R. Behrman. 2014. Population and Demography Assessment Paper: Benefits and Costs of the Population and Demography Targets for the Post-2015 Development Agenda. Tewksbury, MA and
Philadelphia: Copenhagen Consensus Center, University Philadelphia: Copenhagen Consensus Center, University
Authors: Moazzam Ali (WHO), Ben Bellows (Population Council)

This is one of seven Family Planning Evidence Briefs July 11, 2017. The briefs highlight evidence and provide researly . considerations are based on the expert views of the authors, who

\section{Family Planning Evidence Briefs}

Accelerating uptake of voluntary, rights-based family plannin
in developing countries (overview) (Updated October 2018) Family Planning Financing (Updated October 2018) Reducing early and unintended pregnancies among

Improving family planning service delivery in humanitarian

Ensuring
chains - Partnering with the private sector to strengthen provision of

The authors alone are responsible for the views expressed in this article
and they do not necessarily represent the views, decisions or policies of the Family Planning Evidence Brief - Ensuring adequate financing of family
planning commodities and services: WHO/RHR/18.26

- World Health Organization 2018 . Some rights reserved.
This work is available under the CC BY-NC-SA 3.0160 license. H-1211 Geneva 27, Switzerland

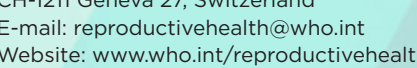
Twitter: @HRPresearch

This material has been funded by UK aid from the UK government, however,
he views expressed do not necessarily reflect the UK government's policics. repared July 2017. Updated October 2018 